\title{
LCZ696 przełomem w leczeniu przewlekłej niewydolności serca z obniżoną frakcją wyrzutową lewej komory
}

\author{
LCZ696 breakthrough in the treatment of chronic heart failure \\ with reduced left ventricular ejection fraction
}

\author{
Sebastian Sobczak, Małgorzata Lelonek \\ Klinika Kardiologii, Katedra Kardiologii i Kardiochirurgii Uniwersytetu Medycznego w Łodzi
}

\begin{abstract}
Heart failure is a common clinical problem; in developed countries it occurs in 1-2\% of the adult population. Despite advances in treatment, outcome the prognosis in this disease remains unfavourable. In the pathophysiology of heart failure with reduced ejection fraction fundamental role play neurohormonal pathways, mainly the activation of the sympathetic nervous system and the renin-angiotensin-aldosterone system, and natriuretic peptides. In the pharmacotherapy of heart failure promising are drugs that modulate the neurohormonal pathways. The paper presents the key results of clinical trials with the new molecule LCZ696, the first angiotensin receptor neprilysin inhibitor (ARNI).
\end{abstract}

Key words: heart failure, neurohormonal system modulation, angiotensin receptor II blocker and neprilysin inhibitor, ARNI

(Folia Cardiologica 2015; 10, 6: 403-409)

\section{Wstęp}

Niewydolność serca jest poważnym i częstym problemem klinicznym; w krajach uprzemysłowionych występuje u 1-2\% dorosłej populacji. Częstość jej występowania zwiększa się z wiekiem i u osób powyżej 70. roku życia dotyczy co dziesiątego seniora [1]. Mimo postępów w diagnostyce i leczeniu niewydolności serca rokowanie w tej jednostce chorobowej wciąż pozostaje niekorzystne; czas przeżycia od pierwszej hospitalizacji do zgonu jest porównywalny z rokowaniem w chorobie nowotworowej [2, 3]. W patofizjologii niewydolności serca z obniżoną frakcją wyrzutową (HFREF, heart failure with reduced ejection fraction) podstawową rolę odgrywają szlaki neurohormonalne, głównie aktywacja układu współczulnego i układu renina-angiotensyna-aldosteron (RAA), oraz układ peptydów natriuretycznych [4]. Potwierdzeniem kluczowego znaczenia układu RAA jest korzystny wpływ blokerów tego układu (inhibitory konwertazy angiotensyny [ACE, angiotensin-converting enzyme], antagoniści receptora $\mathrm{AT}_{1}$ dla angiotensyny II [ARB, angiotensin II type 1 receptor blocker(s)], antagoniści receptora mineralokortykoidowego dla aldosteronu [MRA, mineralocorticoid receptor antagonist]) w leczeniu niewydolności serca [5]. Podobnie korzystne działanie udokumentowano w odniesieniu do hamowania układu współczulnego beta-adrenolitykami [6]. W przypadku nietolerancji lub nieosiągnięcia docelowych wartości częstości rytmu serca za pomocą beta-andrenolityku w grupie pacjentów z obniżoną frakcją wyrzutową nie większą niż 35\% Europejskie Towarzystwo Kardiologiczne (ESC, European Society of Cardiology) zaleca farmakoterapię iwabradyną, czyli wybiórczym blokerem kanału potasowego $\mathrm{I}_{\mathrm{f}} \mathrm{W}$ węźle zatokowym [1]. W tabeli 1 zaprezentowano kluczowe badania kliniczne leków będących obecnie podstawą w farmakoterapii niewydolności serca [7-13].

Mimo istotnego postępu w farmakoterapii w ciągu ostatnich 20 lat dalsze badania są niezbędne w celu poszukiwania leków poprawiających wciąż niekorzystne rokowanie w niewydolności serca. Największe nadzieje pokłada się w molekułach modulujących szlaki neurohormonalne. 
Tabela 1. Kluczowe badania kliniczne leków w niewydolności serca z obniżoną frakcją wyrzutową (źródła [7-13])

\begin{tabular}{|c|c|c|c|c|c|}
\hline Nazwa badania & $\begin{array}{l}\text { Liczba } \\
\text { pacjentów }\end{array}$ & Badana populacja & Terapia & $\begin{array}{l}\text { Pierwszorzędowy } \\
\text { punkt końcowy }\end{array}$ & Wynik \\
\hline SOLVD-T [7] & 2569 & $\begin{array}{l}\text { LVEF } \leq 35 \% \\
\text { I-IV klasa wg NYHA }\end{array}$ & $\begin{array}{l}\text { Enalapril 2,5-10 mg } \\
2 \times / \text { d. v. placebo }\end{array}$ & $\begin{array}{l}\text { Zgon z jakiejkolwiek } \\
\text { przyczyny }\end{array}$ & $\begin{array}{l}\text { Obniżenie ryzyka } \\
\text { zgonu o } 16 \%\end{array}$ \\
\hline CIBIS-II [8] & 2647 & $\begin{array}{l}\text { LVEF } \leq 35 \% \\
\text { III-IV klasa } \\
\text { wg NYHA }\end{array}$ & $\begin{array}{l}\text { Bisoprolol 1,25-10 mg } \\
\text { raz/d. v. placebo }\end{array}$ & $\begin{array}{l}\text { Zgon z jakiejkolwiek } \\
\text { przyczyny }\end{array}$ & $\begin{array}{l}\text { Obniżenie ryzyka } \\
\text { zgonu o 34\% }\end{array}$ \\
\hline RALES [9] & 1663 & $\begin{array}{l}\text { LVEF } \leq 35 \% \\
\text { III-IV klasa } \\
\text { wg NYHA }\end{array}$ & $\begin{array}{l}\text { Spironolakton } 25-50 \mathrm{mg} \\
\mathrm{raz} / \mathrm{d} \text {. v. placebo }\end{array}$ & $\begin{array}{l}\text { Zgon z jakiejkolwiek } \\
\text { przyczyny }\end{array}$ & $\begin{array}{l}\text { Obniżenie ryzyka } \\
\text { zgonu o 30\% }\end{array}$ \\
\hline $\begin{array}{l}\text { CHARM-Alter- } \\
\text { native [10] }\end{array}$ & 2028 & $\begin{array}{l}\text { LVEF } \leq 40 \% \\
\text { II-IV klasa } \\
\text { wg NYHA }\end{array}$ & $\begin{array}{l}\text { Kandesartan 4-32 mg } \\
\mathrm{raz} / \mathrm{d} \text {. v. placebo }\end{array}$ & $\begin{array}{l}\text { Zgon z przyczyn sercowo- } \\
\text {-naczyniowych lub hospi- } \\
\text { talizacja z powodu HF }\end{array}$ & $\begin{array}{l}\text { Obniżenie ryzyka } \\
\text { punktu końcowego } \\
\text { o } 23 \%\end{array}$ \\
\hline $\begin{array}{l}\text { CHARM-Added } \\
{[11]}\end{array}$ & 2548 & $\begin{array}{l}\text { LVEF } \leq 40 \% \\
\text { II-IV klasa } \\
\text { wg NYHA }\end{array}$ & $\begin{array}{l}\text { Kandesartan 4-32 mg } \\
\mathrm{raz} / \mathrm{d} \text {. v. placebo }\end{array}$ & $\begin{array}{l}\text { Zgon z przyczyn sercowo- } \\
\text {-naczyniowych lub hospi- } \\
\text { talizacja z powodu HF }\end{array}$ & $\begin{array}{l}\text { Obniżenie ryzyka } \\
\text { punktu końcowego } \\
\text { o } 15 \%\end{array}$ \\
\hline SHIFT [12] & 6558 & $\begin{array}{l}\text { LVEF } \leq 35 \% \\
\text { II-IV klasa } \\
\text { wg NYHA } \\
H R \geq 70 / \text { min }\end{array}$ & $\begin{array}{l}\text { Iwabradyna } 2,5-7,5 \mathrm{mg} \\
2 \times / \text { d. v. placebo }\end{array}$ & $\begin{array}{l}\text { Zgon z przyczyn sercowo- } \\
\text {-naczyniowych lub hospi- } \\
\text { talizacja z powodu HF }\end{array}$ & $\begin{array}{l}\text { Obniżenie ryzyka } \\
\text { punktu końcowego } \\
\text { o 18\% }\end{array}$ \\
\hline $\begin{array}{l}\text { EMPHASIS-HF } \\
\text { [13] }\end{array}$ & 2737 & $\begin{array}{l}\text { LVEF } \leq 35 \% \\
\text { II klasa wg NYHA }\end{array}$ & $\begin{array}{l}\text { Eplerenon } 25-50 \mathrm{mg} \\
\text { raz/d. v. placeo }\end{array}$ & $\begin{array}{l}\text { Zgon z przyczyn sercowo- } \\
\text {-naczyniowych lub hospi- } \\
\text { talizacja z powodu HF }\end{array}$ & $\begin{array}{l}\text { Obniżenie ryzyka } \\
\text { punktu końcowego } \\
\text { o } 37 \%\end{array}$ \\
\hline
\end{tabular}

\section{LCZ696}

LCZ696 jest pierwszym lekiem z grupy antagonistów receptora dla angiotensyny II i inhibitorem neprylizyny (ARNI, angiotensin receptor II blocker and neprilysin inhibitor). Zawiera on inhibitor neprylizyny (sakubitryl) oraz ARB (walsartan). Neprylizyna jest enzymem proteolitycznym z grupy metaloproteaz; rozkłada i unieczynnia między innymi peptydy natriuretyczne (peptyd natriuretyczny typu A [ANP, A-type natriuretic peptide], peptyd natriuretyczny typu B [BNP, B-type natriuretic peptide]), bradykinine, adrenomedulinę. Hamowanie neprylizyny prowadzi do zwiększenia dostępności peptydów natriuretycznych, które wykazują korzystny wpływ na układ krążenia w niewydolności serca - zwiększają natriurezę oraz diurezę, działają naczyniorozszerzająco oraz hamują niekorzystny remodeling mięśnia sercowego [14]. Należy wspomnieć, że N-końcowy propeptyd natriuretyczny typu B (NT-proBNP, N-terminal of the pro B-type natriuretic peptide) nie jest substratem dla neprylizyny, lecz BNP. Na rycinie 1 przedstawiono mechanizm działania LCZ696.

Warto przypomnieć, że wcześniejsze próby hamowania neprylizyny w połączeniu z inhibitorem ACE (omapatrilat) zakończyły się niepowodzeniem z powodu istotnie zwiększonego ryzyka wstąpienia obrzęku naczynioruchowego. Postuluje się, że za to zjawisko było odpowiedzialne blokowanie trzech enzymów biorących udział w rozkładzie bardykininy, tj. ACE, neprylizyny i prawdopodobnie aminopeptydazy P [16]. Od tej pory nadzieje badaczy skupiły się na LCZ696, który blokuje tylko jeden enzym rozkładający bardykininę - neprylizynę. Poniżej przedstawiono wyniki dwóch zakończonych kluczowych badań nad zastosowaniem LCZ696 w niewydolności serca - PARAMOUNT (Prospective Comparison of ARNI With ARB on Management of Heart Failure With Preserved Ejection Fraction) i PARADIGM-HF.

\section{Badanie PARAMOUNT}

PARAMOUNT to wieloośrodkowe, randomizowane badanie kliniczne II fazy, przeprowadzone metodą podwójnie ślepej próby, służące porównaniu LCZ696 i walsartanu w grupie pacjentów z przewlekłą objawową niewydolnością serca z zachowaną frakcją wyrzutową lewej komory (HFPEF, heart failure with preserved ejection fraction). Do badania włączono 301 pacjentów z objawową niewydolnością serca w II-III klasie według New York Heart Association (NYHA), z frakcją wyrzutową lewej komory większą lub równą 45\% i podwyższonym stężeniem NT-proBNP wynoszącym 400 pg/ml lub więcej. Pacjenci zostali losowo przydzieleni do grupy przyjmującej LCZ696 w dawce 200 mg 2 razy/ /dobę $(n=149)$ lub walsartan w dawce 160 mg 2 razy/ /dobę ( $n=152$ ) przez 36 tygodni. Pierwszorzędowym punktem końcowym było obniżenie stężenia NT-proBNP w ciągu 12 tygodni terapii jako uznanego markera niekorzystnych zdarzeń sercowych wśród pacjentów z niewydolnością serca, również w grupie z zachowaną frakcją wyrzutową 


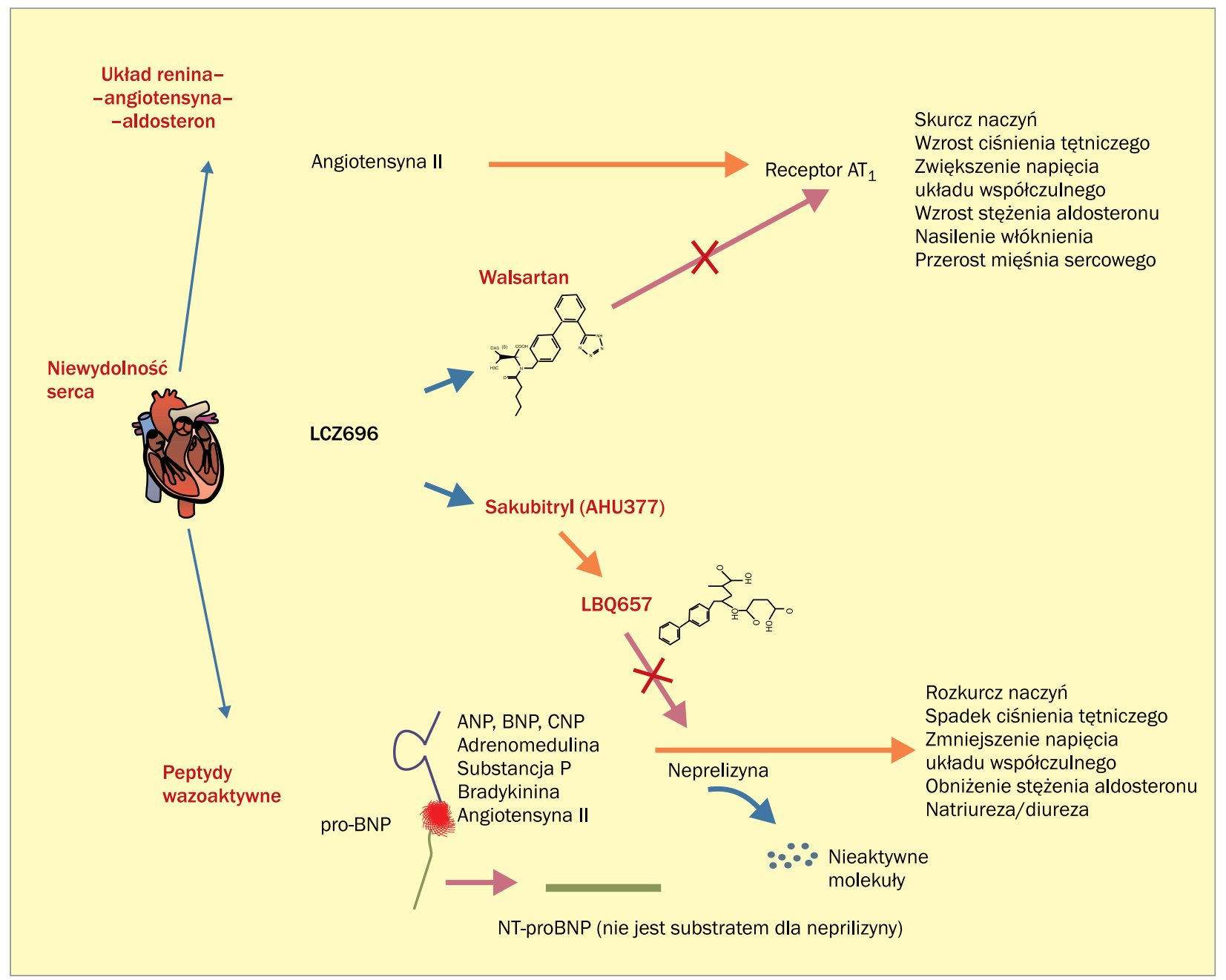

Rycina 1. Mechanizm działania LCZ696 (zmodyfikowano na podstawie [15]); LBQ657 - czynny metabolit sakubitrylu; ANP (A-type natriuretic peptide) - peptyd natriuretyczny typu A; BNP (B-type natriuretic peptide) - peptyd natriuretyczny typu B; CNP (C-type natriuretic peptide) peptyd natriuretyczny typu C; proBNP (pro B-type natriuretic peptide) - propeptyd natriuretyczny typu B; NT-proBNP (N-terminal of the pro B-type natriuretic peptide) - N-końcowy propeptyd natriuretyczny typu B

lewej komory. W badaniu wykazano większą redukcję stężenia NT-proBNP po 12 tygodniach leczenia w grupie przyjmującej LCZ696 (wyjściowo 783 pg/ml, po 12 tygodniach $-605 \mathrm{pg} / \mathrm{ml}$ ) niż w grupie leczonej walsartanem (wyjściowo $862 \mathrm{pg} / \mathrm{ml}$, po 12 tygodniach - $835 \mathrm{pg} / \mathrm{ml}$ ), ze współczynnikiem zmiany stężenia NT-proBNP LCZ696 w stosunku do walsartanu równym 0,77 (95-proc. przedział ufności [Cl, confidence interval] 0,64-0,92; $\mathrm{p}=0,005)$. Ponadto po 36 tygodniach leczenia zarejestrowano istotnie statystycznie większą redukcję wymiarów lewego przedsionka w badaniu echokardiograficznym oraz częstszą poprawę wydolności fizycznej ocenianej według klasyfikacji NYHA. Terapia LCZ696 była dobrze tolerowana; nie odnotowano istotnych statystycznie różnic między grupami w zakresie działań niepożądanych. Obrzęk naczynioruchowy niewymagający hospitalizacji wystąpił u jednego pacjenta leczonego LCZ696 [17].

\section{Badanie PARADIGM-HF}

PARADIGM-HF to wieloośrodkowe, randomizowane badanie kliniczne III fazy, przeprowadzone metodą podwójnie ślepej próby, służące ocenie długoterminowej skuteczności i bezpieczeństwa terapii LCZ696 w porównaniu z enalaprilem w grupie pacjentów z przewlekłą objawową niewydolnością serca z obniżoną frakcją wyrzutową lewej komory poddanych pełnemu, tolerowanemu, zgodnemu $z$ aktualnymi zaleceniami, leczeniu niewydolności serca.

\section{Pacjenci i metody}

Kryteriami włączenia do badania były: wiek powyżej 18. roku życia, objawowa niewydolność serca w II-IV okresie hemodynamicznym według NYHA, frakcja wyrzutowa lewej komory mniejsza lub równa 40\% (zmiana na 35\% 
w okresie badania), stężenie BNP w osoczu większe lub równe 150 pg/ml (lub stężenie NT-proBNP $\geq 600$ pg/ml) na wizycie przesiewowej lub stężenie BNP w osoczu wynoszące 100 pg/ml lub więcej (lub stężenie NT-proBNP $\geq 400 \mathrm{pg} / \mathrm{ml}$ ) i hospitalizacja z powodu niewydolności serca w ciągu ostatnich 12 miesięcy, terapia inhibitorem ACE lub ARB w stabilnych dawkach równoważnych dawce $10 \mathrm{mg} /$ /dobę enalaprilu oraz beta-andrenolityku przez 4 tygodnie poprzedzające włączenie do badania.

Do kryteriów wyłączenia należały: objawowa hipotensja, skurczowe ciśnienie tętnicze poniżej 100 mm Hg podczas wizyty przesiewowej lub poniżej $95 \mathrm{~mm} \mathrm{Hg}$ podczas wizyty randomizacyjnej, upośledzona funkcja nerek definiowana jako szacunkowy współczynnik przesączania kłębuszkowego (eGFR, estimated glomerular filtration rate) poniżej $30 \mathrm{ml} /$ $/ \mathrm{min} / \mathrm{m}^{2}$ powierzchni ciała lub obniżenie wartości eGFR o co najmniej 25\% (zmiana w trakcie badania do 35\%) między wizytą przesiewową a randomizacyjną, stężenie jonów potasu przekraczające 5,2 mmol/I na wizycie przesiewowej lub wynoszące ponad 5,4 mmol/I na wizycie randomizacyjnej, wywiad obrzęku naczynioruchowego lub działań niepożądanych podczas przyjmowania inhibitora ACE lub ARB.

Między grudniem 2009 roku a listopadem 2012 roku do badania włączono 8442 pacjentów, randomizacji poddano 8399 pacjentów, a 43 pacjentów wyłączono z udziału w próbie. Uczestnicy badania zostali losowo przydzieleni do grupy otrzymującej LCZ696 w dawce 200 mg 2 razy/dobę $(n=4187)$ lub enalapril w dawce $10 \mathrm{mg} 2 \mathrm{razy} /$ dobę $(n=4212)$.

Pierwszorzędowy punkt końcowy był punktem złożonym, który obejmował zgon z przyczyn sercowo-naczyniowych lub hospitalizację z powodu niewydolności serca. Drugorzędowy punkt końcowy natomiast stanowiły czas do zgonu z jakiejkolwiek przyczyny, poprawa wyniku punktowego objawów niewydolności serca i ograniczenia aktywności fizycznej według kwestionariusza kardiomiopatii Kansas City (KCCQ, Kansas City Cardiomyopathy Questionnaire) w ciągu 8 miesięcy (zakres 0-100 pkt.; im wyższy wynik, tym mniejsze nasilenie objawów niewydolności serca), czas do pierwszego napadu migotania przedsionków, czas do pierwszorazowego pogorszenia funkcji nerek (schyłkowa niewydolność nerek, obniżenie wartości eGFR o > 50\% lub $0>30 \mathrm{ml} / \mathrm{min} / 1,73 \mathrm{~m}^{2}$ w stosunku do wartości z randomizacji z jednoczesnym spadkiem eGFR < $60 \mathrm{ml} / \mathrm{min} / 1,73 \mathrm{~m}^{2}$ ).

\section{Wyniki}

Ze względu na istotną korzyść z leczenia LCZ696 w porównaniu z enalaprilem zdecydowano o przedterminowym zakończeniu badania w maju 2014 roku. Mediana okresu obserwacji wyniosła 27 miesięcy, bez istotnych różnic w obrębie obu grup.

Pierwszorzędowy punkt końcowy wystąpił istotnie statystycznie rzadziej w grupie leczonej LCZ696 ( $n=914,21,8 \%)$ niż w grupie leczonej enalaprilem $(n=1117 ; 26,5 \%$ ) (ryzyko względne (HR, hazard ratio) $=0,80,95 \% \mathrm{Cl} 0,73-0,87$; p < 0,001). Terapia za pomocą LCZ696, w porównaniu ze stosowaniem enalaprilu, wiązała się z obniżeniem ryzyka zgonu z przyczyn sercowo-naczyniowych o 20\% (13,3\% v. 16,5\%; HR 0,80, 95\% Cl 0,71-0,89; $p<0,001$ ) oraz zmniejszeniem ryzyka hospitalizacji z powodu niewydolności serca o $21 \%$ (12,8\% v. 15,6\%; HR 0,79, 95\% Cl 0,71-0,89; $\mathrm{p}<0,001)$. Na rycinie 2 przestawiono krzywe Kaplana-Meiera odnoszące się do głównych punktów końcowych.

W zakresie drugorzędowych punktów końcowych również istotną przewagę zyskała terapia LCZ696 prowadząca do obniżenia o $16 \%$ ryzyka zgonu z jakiejkolwiek przyczyny (17\% v. 19,8\%; HR 0,86, 95\% Cl 0,76-0,93; p < 0,001) oraz poprawy w zakresie objawów i ograniczenia aktywności fizycznej mierzonych za pomocą KCCQ. Natomiast nie odnotowano istotnych różnic pod względem wystąpienia pierwszego napadu migotania przedsionków oraz zdefiniowanego według protokołu pogorszenia funkcji nerek.

Analiza bezpieczeństwa stosowanej terapii wykazała, że pacjenci otrzymujący LCZ696 rzadziej przerywali przyjmowanie leku ze względu na działania niepożądane (10,7\% v. 12,3\%; $p=0,03)$, natomiast istotnie częściej występowała u nich objawowa hipotensja $(14,0 \%$ v. 9,2\%; $p<0,001)$, jednak rzadko prowadziła do przerwania terapii. Ponadto w grupie leczonej LCZ696, w porównaniu z leczonymi enalaprilem, rzadziej odnotowywano kaszel (11,3\% v. 14,3\%; $\mathrm{p}<0,001)$, hiperkaliemię przekraczającą $6,0 \mathrm{mmol} / \mathrm{l}(4,3 \%$ v. 5,5\%; $p<0,007$ ) oraz stężenie kreatyniny wynoszące ponad $221 \mu \mathrm{mol} / \mathrm{I}(3,3 \%$ v. 4,5\%; $p$ < 0,007). Obrzęk naczynioruchowy wystąpił u 19 pacjentów przyjmujących LCZ696 oraz u 10 pacjentów z grupy leczonej enalaprilem, jednak nie była to zależność istotna statystycznie $(p=0,13)$. W tabeli 2 porównano badania PARADIGM-HF i PARAMOUNT $[14,17]$. W tabeli 3 natomiast zaprezentowano podstawowe właściwości farmakologiczne oraz główne działania niepożądane enalaprilu oraz LCZ696 na podstawie danych z badania PARADIGM-HF [14].

\section{Podsumowanie}

Wyniki badania klinicznego II fazy PARAMOUNT sugerują, że LCZ696 może mieć korzystne działanie w populacji pacjentów z niewydolnością serca z zachowaną frakcją wyrzutową lewej komory. Terapia LCZ696 wiązała się z istotnie statystycznie większym obniżeniem stężenia NT-proBNP niż terapia walsartanem przy podobnym spektrum bezpieczeństwa terapii; NT-proBNP jest markerem zwiększonego naprężenia ścian lewej komory w wyniku przeciążenia ciśnieniowego i objętościowego. Udowodniono, że podwyższona wartość NT-proBNP w grupie pacjentów z niewydolnością serca, również z zachowaną funkcją skurczową, wiąże się ze zwiększonym ryzykiem wystąpienia niekorzystnych zdarzeń sercowych. Terapia LCZ696 prowadząca do istotnego obniżenia wartości NT-proBNP będzie prawdopodobnie 
A Pierwszorzędowy punkt końcowy

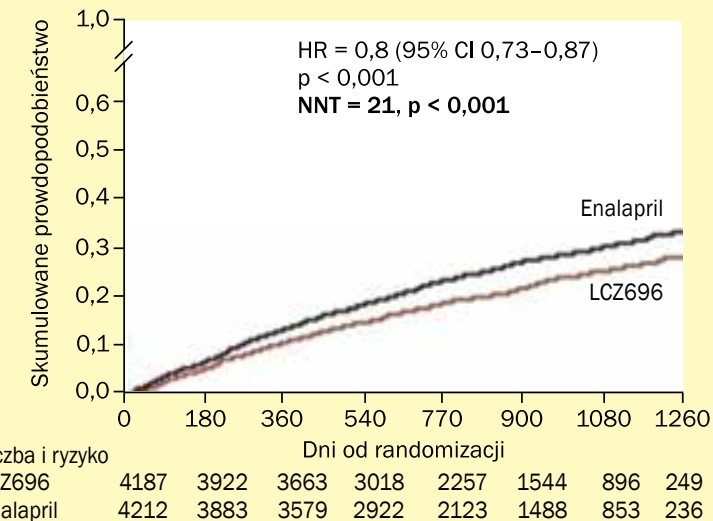

C Hospitalizacja z powodu niewydolności serca

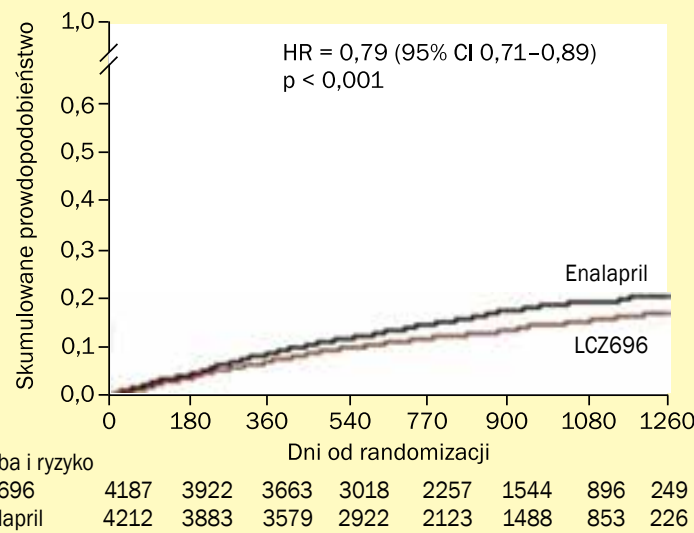

\section{B Zgon z przyczyn sercowo-naczyniowych}

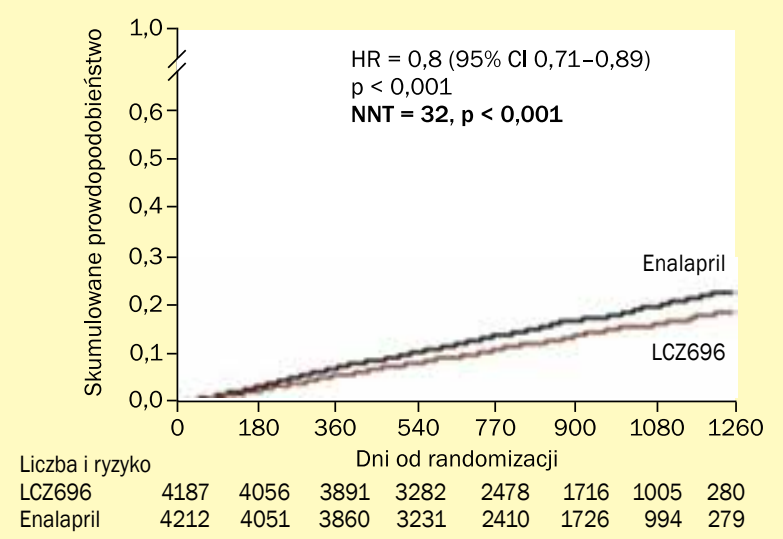

D Zgon niezależnie od przyczyny

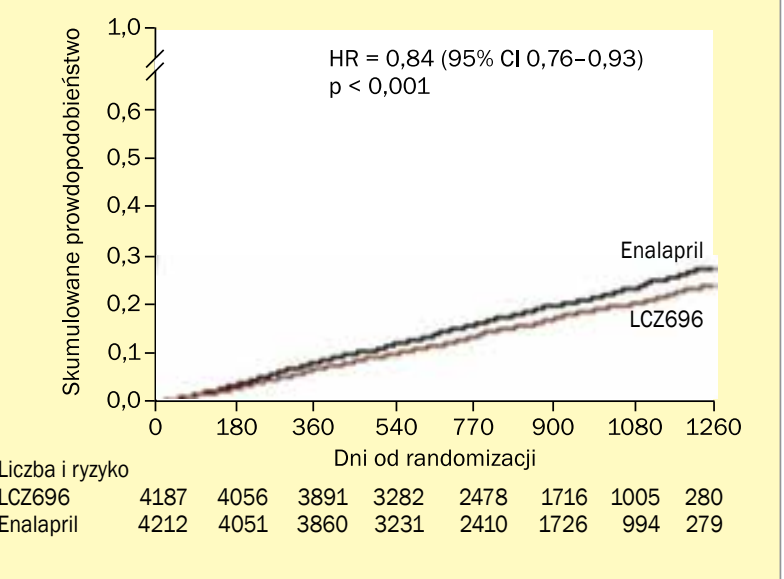

Rycina 2A-D. Krzywe Kaplana-Meiera dla głównych punktów końcowych badania PARADIGM-HF (zmodyfikowano na podstawie [14]); HR (hazard ratio) - ryzyko względne; Cl (confidence interval) - przedział ufności; NNT (numer needed-to-treat) - liczba wymagających leczenia (liczba pacjentów, których trzeba poddać danej interwencji przez określony czas, aby zapobiec 1 niekorzystnemu punktowi końcowemu)

powodowała również zmniejszenie częstości niekorzystnych zdarzeń sercowych. To stwierdzenie jest hipotezą badawczą trwającego badania klinicznego III fazy PARAGON-HF (Prospective Comparison of ARNI with ARB global outcomes In heart failure with preserved ejection fraction) w grupie pacjentów w zachowaną funkcją skurczową lewej komory [15], w którym będą brały udział polskie ośrodki.

Przedstawione wyżej wyniki badania PARADIGM-HF prawdopodobnie będą miały kluczowy wpływ na wytyczne dotyczące farmakoterapii przewlekłej niewydolności serca z obniżoną frakcją wyrzutową. Terapia LCZ696, w porównaniu z leczeniem enalaprilem, wiązała się z istotnie większą redukcją ryzyka zgonu z przyczyn sercowo-naczyniowych, ryzyka hospitalizacji z powodu niewydolności serca, ryzyka zgonu z jakiejkolwiek przyczyny oraz powodowała poprawę w zakresie objawów i ograniczenia aktywności fizycznej ocenianych za pomocą KCCQ. Ponadto terapia LCZ696 była stosunkowo dobrze tolerowana i nie prowadziła do wystę- powania częstszych działań niepożądanych niż stosowanie enalaprilu. Poza tym, na podstawie ostatnio opublikowanej pośredniej analizy LCZ696 z PARADIGM-HF w porównaniu z placebo z badań SOLVD-T i CHARM-Alternative, wykazano, że LCZ696 w porównaniu z placebo powinno obniżać ryzyko zgonu z przyczyn sercowo-naczyniowych o 32-34\% ( $p<0,001)$, ryzyko hospitalizacji z powodu niewydolności serca - o 46-49\% $(p<0,0001)$ i ryzyko śmiertelności całkowitej - o 26-28\% $(p<0,005)$ [18]. Na podstawie powyższych badań wydaje się, że LCZ696 będzie zalecanym lekiem w pierwszej linii farmakoterapii pacjentów z niewydolnością serca z obniżoną frakcją wyrzutową lewej komory, natomiast badanie PARAGON-HF pokaże, czy lek ten zajmie równie wysoką pozycję w grupie pacjentów z zachowaną frakcją wyrzutową.

\section{Konflikt interesów}

Autorzy uczestniczą w badaniu PARAGON-HF. 
Tabela 2. Dane z najważniejszych badań nad LCZ696 - PARADIGM-HF i PARAMOUNT (na podstawie [14, 17])

\begin{tabular}{|c|c|c|}
\hline & PARADIGM-HF & PARAMOUNT \\
\hline Liczba pacjentów & 8442 & 301 \\
\hline Badana populacja & $\begin{array}{l}\text { LVEF } \leq 40 \% \\
\text { II-IV klasa wg NYHA }\end{array}$ & $\begin{array}{l}\text { LVEF } \geq 45 \% \\
\text { II-III klasa wg NYHA } \\
\text { Stężenie NT-proBNP } \geq 400 \text { pg/ml }\end{array}$ \\
\hline Terapia & $\begin{array}{l}200 \mathrm{mg} 2 \times / \text { d. LCZ696 w dawce v. } 10 \mathrm{mg} \\
2 \times / \text { d. enalaprilu }\end{array}$ & $\begin{array}{l}200 \mathrm{mg} 2 \times / \text { d. LCZ696 v. } 160 \mathrm{mg} 2 \text { ×/d. } \\
\text { walsartanu }\end{array}$ \\
\hline Pierwszorzędowy punkt końcowy & $\begin{array}{l}\text { Zgon z przyczyn sercowo-naczyniowych } \\
\text { lub hospitalizacja z powodu niewydolności } \\
\text { serca }\end{array}$ & $\begin{array}{l}\text { Obniżenie stężenia NT-proBNP } \\
\text { w ciągu } 12 \text { tygodni terapii }\end{array}$ \\
\hline Wyniki & $\begin{array}{l}\text { Obniżenie ryzyka wystąpienia pierwszo- } \\
\text { rzędowego punktu końcowego o } 20 \%\end{array}$ & Większa redukcja stężenia NT-proBNP \\
\hline Drugorzędowe punkty końcowe & $\begin{array}{l}\text { 1. Czas do zgonu z jakiejkolwiek przyczyny } \\
\text { 2. Poprawa wyniku punktowego w KCCQ } \\
\text { 3. Czas do pierwszego napadu migotania } \\
\text { przedsionków } \\
\text { 4. Czas do pierwszorazowego pogorszenia } \\
\text { funkcji nerek }\end{array}$ & $\begin{array}{l}\text { 1. Zmiany parametrów echokardiograficznych: } \\
\text { - wielkości LV i LVEF } \\
\text { - wielkości LA } \\
\text { 2. wskaźników funkcji rozkurczowej } \\
\text { 2. Zmiana ciśnienia tętniczego } \\
\text { 3. Zmiana klasy wg NYHA } \\
\text { 4. Poprawa wyniku punktowego w KCCQ }\end{array}$ \\
\hline Wyniki & $\begin{array}{l}\text { 1. Obniżenie ryzyka zgonu o } 16 \% \\
\text { 2. Poprawa wyniku o 1,64 pkt. } \\
\text { 3. Brak istotnej różnicy } \\
\text { 4. Brak istotnej różnicy }\end{array}$ & $\begin{array}{l}\text { 1. Zmiany parametrów echokardiograficznych: } \\
\text { - brak istotnej różnicy } \\
\text { - zmniejszenie wymiarów LA } \\
\text { - brak istotnej różnicy } \\
\text { 2. Większa redukcja wartości SBP i DBP } \\
\text { 3. Zmniejszenie klasy wg NYHA } \\
\text { 4. Brak istotnej różnicy }\end{array}$ \\
\hline
\end{tabular}

LVEF (left ventricular ejection fraction) - frakcja wyrzutowa lewej komory; NYHA - New York Heart Association; NT-proBNP (N-terminal of the pro B-type natriuretic peptide) - N-końcowy propeptyd natriuretyczny typu B; LV (left ventricle) - lewa komora; LA (left atrium) - lewy przedsionek; KCCQ (Kansas City Cardiomyopathy Questionnaire) - kwestionariusz kardiomiopatii Kansas City; SBP (systolic blood pressure) - skurczowe ciśnienie tętnicze; DBP (diastolic blood pressure) - rozkurczowe ciśnienie tetnicze

Tabela 3. Podstawowe właściwości farmakologiczne i główne działania niepożądane enalaprilu oraz LCZ696 na podstawie badania PARADIGM-HF (na podstawie [14])

\begin{tabular}{|c|c|c|}
\hline & Enalapril & LCZ696 \\
\hline Mechanizm działania & Inhibitor ACE & $\begin{array}{l}\text { Blokada receptora } \mathrm{AT}_{1} \\
\text { Inhibitor neprylizyny }\end{array}$ \\
\hline Postać leku & Prolek - enalapril & Walsartan i prolek - AHU377 \\
\hline Czynny metabolit & & LBQ657 \\
\hline Wiązanie z białkami osocza & Dla enalaprilu 40-50\% & $>96 \%$ \\
\hline Wydalanie & $\begin{array}{l}\text { Enalaprilat } \\
40-50 \% \text { z moczem }\end{array}$ & $\begin{array}{l}\text { Walsartan: ok. 83\% z kałem, } 13 \% \text { z moczem } \\
\text { LBQ657: 52-68\% z moczem, 37-48\% z kałem }\end{array}$ \\
\hline Okres półtrwania $\left(\mathrm{T}_{1 / 2}\right)$ & $11 \mathrm{~h}$ & $\begin{array}{l}\text { Walsartan: } 8,9-16,6 \mathrm{~h} \\
\text { LBQ657: } 9,9-11,1 \mathrm{~h}\end{array}$ \\
\hline Objawowa hipotensja & $9,2 \%$ & $14 \%$ \\
\hline Podwyższone stężenie kreatyniny $\geq 221 \mu \mathrm{mol} / \mathrm{l}$ & $4,5 \%$ & $3,3 \%$ \\
\hline Hiperkaliemia $\geq 6$ mmol/l & $5,6 \%$ & $4,3 \%$ \\
\hline Kaszel & $14,3 \%$ & $11,3 \%$ \\
\hline Obrzęk naczynioruchowy & 10 pacjentów & 19 pacjentów \\
\hline $\begin{array}{l}\text { Obrzęk naczynioruchowy z niewydolnością } \\
\text { oddechową }\end{array}$ & 0 pacjentów & 0 pacjentów \\
\hline
\end{tabular}




\section{Streszczenie}

Niewydolność serca jest częstym problemem klinicznym; w krajach uprzemysłowionych występuje u 1-2\% dorosłej populacji. Mimo postępów w leczeniu rokowanie w tej jednostce chorobowej pozostaje niekorzystne. W patofizjologii niewydolności serca z obniżoną frakcją wyrzutową podstawową rolę odgrywają szlaki neurohormonalne - głównie aktywacja układu współczulnego i układu renina-angiotensyna-aldosteron - oraz układ peptydów natriuretycznych. W farmakoterapii niewydolności serca obiecujące wydają się leki modulujące szlaki neurohormonalne.

W pracy zaprezentowano wyniki kluczowych badań klinicznych nad nową molekułą - LCZ696 - pierwszym antagonistą receptora dla angiotensyny inhibitorem neprylizyny (ARNI).

Słowa kluczowe: niewydolność serca, modulacja układu neurohormonalnego, antagonista receptora dla angiotensyny II i inhibitor neprylizyny, ARNI

(Folia Cardiologica 2015; 10, 6: 403-409)

\section{Piśmiennictwo}

1. McMurray J.J., Adamopoulos S., Anker S.D. i wsp. ESC Guidelines for the diagnosis and treatmentof acute and chronic heart failure 2012The Task Force for the Diagnosis and Treatment of Acute and Chronic Heart Failure 2012 of the European Society of Cardiology. Developed in collaboration with the Heart Failure Association (HFA) of the ESC. Eur. Heart J. 2012; 33: 1787-1847.

2. Jhund P.S., Macintyre K., Simpson C.R. i wsp. Long-term trends in first hospitalization for heart failure and subsequent survival between 1986 and 2003: a population study of 5.1 million people. Circulation 2009; 119: 515-523.

3. Stewart S., Maclntyre K., Hole D.J. i wsp. More 'malignant' than cancer? Five-year survival following a firstadmission for heart failure. Eur. J. Heart Fail. 2001; 3: 315-322.

4. Swedberg K. Importance of neuroendocrine activation In chronic heart failure. Impact on treatment strategies. Eur. J. Heart Fail. 2000; 2: 229-233.

5. McMurray J.J. CONSENSUS to EMPHASIS: the overwhelming evidence which makes blockade of the rennin-angiotensin-aldosterone system the cornerstone of therapy for systolic heart failure. Eur. J. Heart Fail. 2011; 13: 929-936.

6. Shibata M.C., Flather M.D., Wang D. Systematic review of the impact of beta blockers on mortality and hospital admissions in heart failure. Eur. J. Heart Fail. 2001; 3: 351-357.

7. The SOLVD Investigators. Effect of enalapril on survival in patients with reduced left ventricular ejectionfractions and congestive heart failure. N. Engl. J. Med. 1991; 325: 293-302.

8. CIBIS-II Investigators and Committees. The cardiac Insufficiency Bisoprolol Study II (CIBIS-II): a randomised trial. Lancet 1999; 353: 9-13.

9. Pitt B., Zannad F., Remme W.J. i wsp. The effect of spironolactone on morbidity and mortality in patients with severe heart failure. N. Engl. J. Med. 1999: 341: 709-717.

10. Granger C.B., MacMurray J.J., Yusuf S. i wsp. Effects of candesartan in patients with chronic heart failure and reduced left-ventricular systolic function intolerant to angiotensin-converting-enzyme inhibitors: the CHARM-Alternative trial. Lancet 2003; 362: 772-776.

11. McMurray J.J., Östergren J., Swedberg K. i wsp. Effects of candesar$\tan$ in patients with chronic heart failure and reduced left-ventricular systolic function taking angiotensin converting-enzyme inhibitors: the CHARM-Added trial. Lancet 2003; 362: 767-771.

12. Swedberg K., Komajda M., Bohm M. i wsp. Ivabradine and outcomes in chronic heart failure (SHIFT): a randomised placebo-controlled study. Lancet 2010; 376: 875-885.

13. Zannad F., McMurray J.J., Krum H. i wsp. Eplerenone in patients with systolic heart failure and mild symptoms. N. Engl. J. Med. 2011; 364: 11-21.

14. McMurray J.J., Packer M., Desai A.S. i wsp. Dual angiotensin receptor and neprilysin inhibition as an alternative to angiotensinconverting enzyme inhibition in patients with chronic systolic heart failure: rationale for and design of the Prospective comparison of ARNI with ACEI to Determine Impact on Global Mortality and morbidity in Heart Failure trial (PARADIGM-HF). Eur. J. Heart Fail. 2013; 15: 1062-1073.

15. Vardeny O., Miller R., Solomon S.D. Combined neprilysin and renin-angiotensin system inhibition for the treatment of heart failure. JACC Heart Fail. 2014; 2: 663-670.

16. Packer M., Califf R.M., Konstam M.A. i wsp. Comparison of omapatrilat and enalapril in patients with chronic heart failure: the Omapatrilat Versus Enalapril Randomized Trial of Utility in Reducing Events (OVERTURE). Circulation 2002; 106: 920-926.

17. Solomon S.D., Zile M., Pieske B. i wsp. The angiotensin receptor neprilysin inhibitor LCZ696 in heart failure with preserved ejection fraction: a phase 2 double blind randomised controlled trial. Lancet 2012; 380: 1387-1395.

18. McMurray J.J., Packer M., Desai A. i wsp. A putative placebo analysis of the effects of LCZ 696 on clinical outcomes in heart failure. Eur. Heart J. 2015; 36: 434-439. 